\title{
Economic Growth Modelling in West Nusa Tenggara Using Bayesian Spatial Model Approach
}

\author{
Siti Soraya ${ }^{1 *}$, Baiq Candra Herawati ${ }^{2}$, Habib Ratu Perwira Negara ${ }^{3}$ \\ 1,2,3 Computer Science, Universita Bumigora, Indonesia \\ 1itisorayaburhan@universitasbumigora.ac.id, ${ }^{2}$ candrah@universitasbumigora.ac.id \\ 3habib.ratu@universitasbumigora.ac.id
}

\begin{abstract}
\section{Article History:}

Received : 09-11-2020

Revised : 15-03-2021

Accepted : 01-04-2021

Online : :16-04-2021

\section{Keyword:}

Economic Growth;

Bayesian;

Heterogeneity;

GRDP;

Spatial.

\section{0}

Qxista

暂地

Givai

Economic growth is a measure of the welfare of the people in an area. Economic movement is characterized by the number of goods and services produced. The high amount of goods produced and the services used are of course strongly influenced by the amount of available capital, the labor involved, and the level of technology used. The measuring instrument or a reflection of economic growth is the Gross Regional Domestic Product (GRDP). The purpose of this study is to model economic growth in NTB in 2018. In this study, GRDP modeling was carried out using the Bayesian Spatial approach. Based on the results of testing the spatial dependency and spatial heterogeneity, it shows that there is a spatial dependence on the GRDP of districts / cities in NTB Province.. From the analysis conducted, it was found that $\rho$ was positive and insignificant at the $10 \%$ level. The parameter estimation results show that the number of workers, the value of capital and the number of workers weighed are variables that have a significant effect on the model. Thus the GRDP of an area in West Nusa Tenggara is influenced by the number of workers, the value of capital and the total labor weight and the GRDP of other surrounding areas.
\end{abstract}

\section{A. INTRODUCTION}

Economic growth is a measure of the welfare of the people in an area (Surya et al., 2021). Economic movements resulting from the amount of goods and services produced or produced (Sainsbury, 2020)(Asatryan \& Feld, 2015). The high amount of goods produced and services used is of course highly readable by the amount of available capital, the workforce involved, and the level of technology used (Chica-Olmo et al., 2020). The measuring instrument or a reflection of economic growth is the Gross Regional Domestic Product (GRDP), (Sainsbury, 2020), (Gründler \& Potrafke, 2019).

GRDP can be said to be good if it is supported by sufficient capital, adequate manpower and technology capable of facilitating the process of economic movement (Saeed et al., 2020)(Eris \& Ulasan, 2013). However, this condition of economic movement is often faced with various obstacles, especially in terms of production, namely the difference in economic processes in producing goods and services. This ultimately results in differences in the need for and supply of capital, labor and technology (Yolanda et al., 2019), (Alinaitwe, 2012). 
West Nusa Tenggara Province is one of the regions in Indonesia which has abundant natural resources and adequate human resources. Economic activities occur in various sectors, such as agriculture, industry, trade, hotels and restaurants, transportation and communications as well as mining and services. When viewed from natural resources and various sectors that drive the economy, of course the NTB Province is at the forefront of the largest contributor to GRDP in Indonesia. However, this is not going very well, marked by the high level of crime that occurs, for economic reasons. The world of tourism, which is a source of income, is also not enough to make people meet their needs (J. $\mathrm{Li} \& \mathrm{Li}, 2020$ ).

NTB Province consists of 2 islands, namely Lombok Island and Sumbawa Island. The phenomenon that occurs in NTB's economic activities is that people from the island of Sumbawa look for work and even settle on the island of Lombok. This is done for, among other reasons, life expectancy, expenditure per capita, and local revenue. So the residents make a living outside the city or outside the island (Syam et al., 2020). It is not uncommon for only a few to settle in their own territory. So indirectly, with the large number of immigrants from outside the city / outside the island, of course, it helps to move the economy and development in the Lombok island region can even become a booster for the economy in the Lombok region (Mustaqim et al., 2019). Based on several descriptions of the problems faced above, sometimes the economy of the Lombok Island region is influenced by labor from the island of Sumbawa, as well as capital formed and other factors. Even the conditions of economic growth between the two islands will influence each other. With the background of the problems described, this study aims to make a modeling of the economic growth of the NTB Government and the factors that influence it using the Spatial Bayesian Method.

\section{B. METHOD}

This type of research is quantitative. The method used is Bayesian Spatial. Bayesian Spatial Method is a term used to model spatial regression models with the help of bayesians. Such as the use of prior and posterior and full-conditional distributions in estimating parameters that cannot be accommodated by the maximum likelihood in general. The data used in this research is secondary data obtained from Central Statistics Agency NTB and State Electricity Company NTB. The data that becomes the object of research are data on the value of GRDP, labor, and the electrification ratio. Several stages of research can be described through the following steps : (1) Determine the response variable and predictor variable from the data that has been obtained, (2) Describe each variable in the study as an illustration of the economy in West Nusa Tenggara and the factors that are thought to influence it, (3) Identifying the relationship pattern between response variables and predictor variables through the Scatter Plot, (4) Assign a spatial weighting matrix for each area using the Queen Contiquity weight, (5) Testing the spatial aspects (spatial dependency and spatial heterogeneity) (Liu \& Zhu, 2017), (6) Test the appropriate spatial model using the Lagrange Multiplier (Chica-Olmo et al., 2020), (7) Determine the likelihood function, (8) Set prior, (9) Get a joint distribution function (Joint Distribution) (Han et al., 2020), (10) Form a full conditional posterior distribution, (11) Carry out the Markov Chain Monte Carlo (MCMC) process (Seya et al., 2012), (12) Evaluating the model that has been formed , and (13) Interpret the model that has been obtained . 


\section{RESULT AND DISCUSSION}

\section{Decription of NTB Economic Growth}

General information that can be explained from NTB's economic growth can be seen from descriptive statistics of NTB's GRDP growth. The average GRDP growth of NTB was 9772.78 billion rupiah. The lowest GRDP was achieved by Kota Bima with a value of 4848 billion rupiah. Meanwhile, Central Lombok Regency received the highest GRDP with a value of 13771 billion rupiah. The GRDP growth rate of each district / city in NTB is shown in Figure 1.

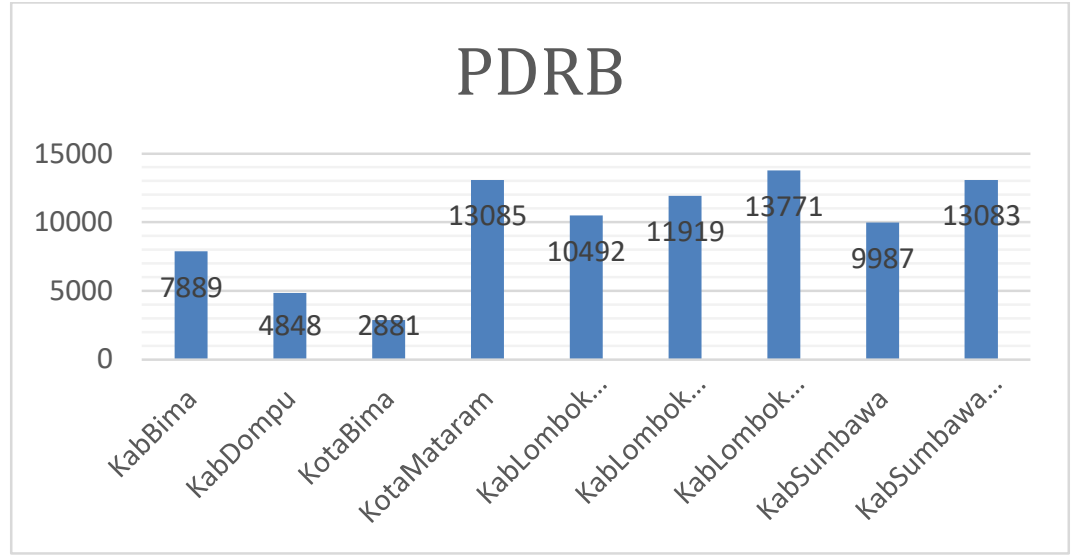

Figure 1. Level of Distribution of GRDP

\section{Description of Factors Affecting NTB Economic Growth}

An overview of the labor, capital and electrification ratios that affect GRDP growth in NTB can be seen in Table 1.

Table 1. Description of Factors Affecting Economic Growth in NTB

\begin{tabular}{lrrrr}
\hline \multicolumn{5}{c}{ Statistics } \\
\hline & \multicolumn{1}{c}{ PDRB } & \multicolumn{1}{c}{ Modal } & Tenaga_Kerja & \multicolumn{1}{c}{ RE } \\
\hline Mean & 9772,78 & 1624575499,89 & 3128,33 & 96,33 \\
\hline Std. Deviation & 3846,789 & 517632762,678 & 3046,783 & 10,513 \\
\hline Minimum & 2881 & 768070688 & 668 & 84 \\
\hline Maximum & 13771 & 2541232033 & 8588 & 116 \\
\hline Sum & 87955 & 14621179499 & 28155 & 867 \\
\hline
\end{tabular}

From Table 1, it can be illustrated that the average number of workers who contributed to the growth of NTB's GRDP was 3128.33 people with a minimum number of 668 people and a maximum of 8588 people. The district / city that gave the lowest contribution was Bima City and the highest was Central Lombok Regency. Furthermore, the average amount of capital channeled into NTB's GRDP growth was 1624575499.89 billion rupiah with a minimum amount of 768070688 billion rupiah and a maximum amount of 2541232033 billion rupiah. The district / city that gave the lowest capital contribution was Bima City and the highest was East Lombok. The electrification ratio provides information that the average electrification ratio that contributes to the growth of NTB's GRDP is 96.33 with a minimum amount of 84 and a maximum of 116 . The districts / cities that provide the lowest contribution are Bima City and the highest is West Lombok. 


\section{Relationship between Response Variables and Predictor Variables}

The relationship between the response variable and the predictor variable can be seen in the Scatter Plot in Figure 2.

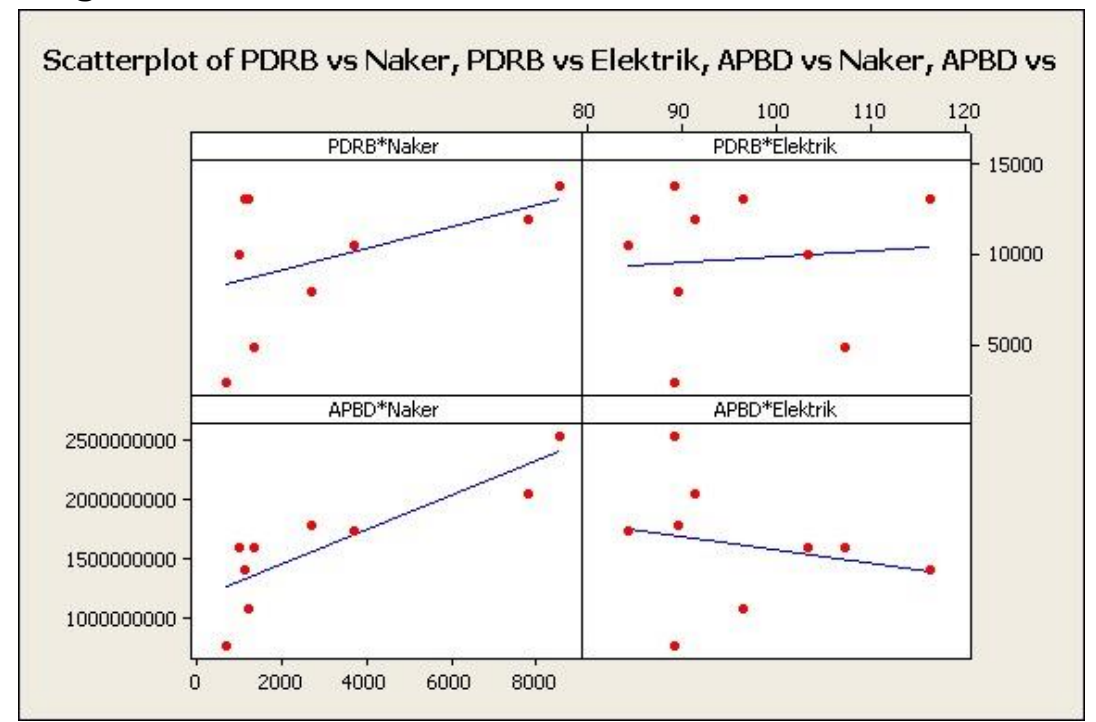

Figure 2. Scater Plot between Response Variables and Predictor Variables

Based on Figure 2, it is known that the factors that influence the value of GRDP have a positive correlation pattern which means that the higher the labor, capital, and electrification ratios, the greater the resulting GRDP. In the plot of manpower to GRDP, there are still observations that are far from the linear line. This shows that the diversity of data is still quite high. The trend of data distribution from the scatter plot on capital tends to be higher than the other plot (Ma et al., 2015).

\section{Testing of Spatial Effects}

The hypothesis used in testing the spatial dependence with the LM test is as follows (Bera et al., 2019):

$H_{0}: \rho=0$ (there is no spatial dependency on the model)

$H_{1}: \rho \neq 0$ (there is a spatial dependency on the model)

Testing of spatial dependencies using GeoDa software can be seen in Table 2.

Tabel 2. Spatial Dependency Test

\begin{tabular}{lccc}
\hline TEST & MI/DF & VALUE & PROB \\
\hline Lagrange Multiplier (lag) & 1 & 1,471 & 0,225 \\
\hline Robust LM (lag) & 1 & 4,936 & 0,026 \\
\hline
\end{tabular}

Based on Table 2, it can be seen that there is a spatial dependency on the model. Referring to the significance of the Robust LM (lag) (Xu et al., 2020), the model formed is the Spatial Autoregressive (SAR) model (Kostov, 2013). States that the SAR model obtained through the spatial dependency test can indicate the formation of a new model or a specificity for the model, namely the Spatial Durbin Model (SDM) (B. Li \& Wu, 2017).

Heteroscedasticity testing was performed using the Breusch-Pagan test. The hypothesis used in the Breusch-Pagan test is (Marie Therese S. Sario, 2018):

$H_{0}: \sigma_{1}{ }^{2}=\sigma_{2}{ }^{2}=\cdots=\sigma_{n}{ }^{2}=\sigma^{2} \quad$ (Homoscedasticity)

$H_{1}:$ there is at least one ${\sigma_{i}}^{2} \neq \sigma^{2}$ with $i=1,2, \ldots, n$ (Heteroscedasticity) 
The test results with the Breusch-Pagan test can be seen in Table 3.

Tabel 3. Heteroscedasticity Test

\begin{tabular}{lr}
\hline Breush-Pagan LM-statistic & 11,908 \\
\hline Chi-squared probability & 0,0294 \\
\hline Degrees of freedom & 3 \\
\hline
\end{tabular}

Based on Table 3, it is known that the Breusch-Pagan value is 11.908 , while the chi-square table value with 3 degrees of freedom at $5 \%$ alpha is 7.815 . Based on the results obtained, it is concluded that reject $\mathrm{H}_{-} 0$, which means there is heterogeneity in the data.

\section{Estimation Results and Significance Test of Model Parameters}

Table 4 shows the results of the Estimation Spatial Model regression with Bayesian approach

Table 4. Bayesian Spatial Model Estimation

\begin{tabular}{lccc}
\hline \multicolumn{1}{c}{ Variable } & Coefficient & Std Deviation & p-level \\
\hline Constant & $-14,602$ & 8,283 & 0,002 \\
\hline Tenaga_Kerja & 0,309 & 0,042 & 0,025 \\
\hline Modal & 0,834 & 0,072 & 0,012 \\
\hline Rasio_Elektrifikasi & 0,243 & 1,133 & 0,220 \\
\hline W-Tenaga_Kerja & 0,752 & 0,009 & 0,043 \\
\hline W-Modal & $-0,062$ & 0,051 & 0,344 \\
\hline W-Rasio_Elektrifikasi & 0,401 & 5,842 & 0,342 \\
\hline Rho & 0,899 & 0,037 & 0,129 \\
\hline R-Squared & 0,876 & \\
\hline \multicolumn{4}{l}{ Significance $=10 \%$} \\
\end{tabular}

The value of the coefficient $\rho$ in Table 4 is positive, which is 0.899 , with a p-level of 0.129 . So it can be concluded that there is no significant relationship at $\alpha=10 \%$. A positive rho value indicates a spatial dependence that occurs between regions in NTB. Besides that, the coefficient value of the labor, capital, weighted labor variables is also positive and significant. Only the electrification ratio, weighted capital and weighted electrification ratio are negative and insignificant. In general, it can be concluded that the level of diversity of economic growth is indicated by the resulting R-squared value of 0.876 . This implies that $87.6 \%$ of economic growth can be explained by the model formed. Meanwhile, $12.9 \%$ cannot be explained by the model, because there are other variables which actually influence but are not included in the model.

The Bayesian Spatial Model that is formed can provide information that the magnitude of the GRDP $(y)$ value of an area in NTB, apart from being influenced by labor $\left(X_{1}\right)$, capital $\left(X_{2}\right)$, the electrification ratio $\left(X_{3}\right)$ of the region, is also influenced by the GRDP value $(y)$ nearby area. Apart from that, it is also influenced by the workforce from other regions $\left(W X_{1}\right)$ which borders the area. An example of the Central Lombok model which has a spatial influence on the $y$ variable and the $x$ variable:

$$
\hat{y}_{i}=-14,602+0,899 \sum_{j=1}^{9} W_{i \neq j} y_{j}+0,309 X_{1 i}+0,834 X_{2 i}+0,243 X_{3 i}
$$


85 | JTAM (Jurnal Teori dan Aplikasi Matematika) | Vol. 5, No. 1, April 2021, pp. 80-87

$$
\begin{aligned}
+0,752 \sum_{j=1}^{9} W_{i \neq j} & X_{1 i}-0,062 \sum_{j=1}^{9} W_{i \neq j} X_{2 i}+0,401 \sum_{j=1}^{9} W_{i \neq j} X_{3 i} \\
\hat{y}_{\text {Lombok Tengah }} & \\
& =-14,602+0,899\left(\frac{1}{3}\right)\left(y_{\text {Kab LombokBarat }}+y_{\text {Kota Mataram }}\right. \\
& \left.+y_{\text {Kab LombokTimur }}\right)+0,3096 X_{1}+0,834 X_{2}+0,243 X_{3} \\
& +0,752\left(\frac{1}{3}\right)\left(X_{1(\text { Kab LombokBarat })}+X_{1(\text { Kota Mataram })}\right. \\
& \left.+X_{1(\text { Kab LombokTimur })}\right) \\
& -0,062\left(\frac{1}{3}\right)\left(X_{2(\text { Kab LombokBarat })}+X_{2(\text { Kota Mataram })}\right. \\
& \left.+X_{2(\text { Kab LombokTimur })}\right) \\
& +0,401\left(\frac{1}{3}\right)\left(X_{3(\text { Kab LombokBarat })}+X_{3(\text { Kota Mataram })}\right. \\
& \left.+X_{3(\text { Kab LombokTimur })}\right)
\end{aligned}
$$

\section{CONCLUSION AND SUGGESTIONS}

Based on the analysis and discussion carried out, it can be concluded that the magnitude of the GRDP value of an area in NTB is not only influenced by the number of workers, regional capital, but also by the GRDP and labor from other nearby areas, with a significance level of $10 \%$. The models formed for each observation in NTB are:

$$
\begin{aligned}
\hat{y}_{i}= & -14,602+0,899 \sum_{j=1}^{9} W_{i \neq j} y_{j}+0,309 X_{1 i}+0,834 X_{2 i}+0,243 X_{3 i} \\
& +0,752 \sum_{j=1}^{9} W_{i \neq j} X_{1 i}-0,062 \sum_{j=1}^{9} W_{i \neq j} X_{2 i}+0,401 \sum_{j=1}^{9} W_{i \neq j} X_{3 i}
\end{aligned}
$$

Things that can be used as suggestions are related to the application of spatial bayesian to panel data and the use of weights other than queen such as costomize.

\section{ACKNOWLEDGEMENT}

Our gratitude goes to all members of the research team, as well as DRPM DITJEN DIKTI who have supported this research through the Beginner Lecturer Research Grant (PDP). Thanks also to Central Statistics Agency NTB and State Electricity Company NTB, and the Office of Manpower in NTB for the data that has been provided.

\section{REFERENCES}

Alinaitwe, G. (2012). Determinants of Economic Growth in Africa with Emphasis on the Role of Financial Markets Using Bayesian Averaging Of Classical Estimates. 4(May), 93-114. http://hdl.handle.net/2381/10911

Asatryan, Z., \& Feld, L. P. (2015). Revisiting the link between growth and federalism: A Bayesian model averaging approach. Journal of Comparative Economics, 43(3), 772-781. https://doi.org/10.1016/j.jce.2014.04.005 
Bera, A. K., Doğan, O., Taşpınar, S., \& Leiluo, Y. (2019). Robust LM tests for spatial dynamic panel data models. Regional Science and Urban Economics, 76(October 2017), 47-66. https://doi.org/10.1016/j.regsciurbeco.2018.08.001

Chica-Olmo, J., Salaheddine, S. H., \& Moya-Fernández, P. (2020). Spatial relationship between economic growth and renewable energy consumption in 26 European countries. Energy Economics, 92, 104962. https://doi.org/10.1016/j.eneco.2020.104962

Eris, M. N., \& Ulasan, B. (2013). Trade openness and economic growth: Bayesian model averaging estimate of cross-country growth regressions. Economic Modelling, 33, 867883. https://doi.org/10.1016/j.econmod.2013.05.014

Gründler, K., \& Potrafke, N. (2019). Corruption and economic growth: New empirical evidence. European Journal of Political Economy, 60(August), 101810. https://doi.org/10.1016/j.ejpoleco.2019.08.001

Han, X., Lee, L.-F., \& Xu, X. (2020). Large Sample Properties of Bayesian Estimation of Spatial Econometric Models. Econometric Theory, 1-39. https://doi.org/10.1017/s0266466620000286

Kostov, P. (2013). Spatial Weighting Matrix Selection in Spatial Lag Econometric Model. Econometrics, 1(1), 20-30. https://doi.org/10.12966/e.05.01.2013

Li, B., \& Wu, S. (2017). Effects of local and civil environmental regulation on green total factor productivity in China: A spatial Durbin econometric analysis. Journal of Cleaner Production, 153, 342-353. https://doi.org/10.1016/j.jclepro.2016.10.042

Li, J., \& Li, S. (2020). Energy investment, economic growth and carbon emissions in ChinaEmpirical analysis based on spatial Durbin model. Energy Policy, 140(March), 111425. https://doi.org/10.1016/j.enpol.2020.111425

Liu, H., \& Zhu, X. (2017). Joint modeling of multiple crimes: A Bayesian spatial approach. ISPRS International Journal of Geo-Information, 6(1). https://doi.org/10.3390/ijgi6010016

Ma, T., Hong, T., \& Zhang, H. (2015). Tourism spatial spillover effects and urban economic growth. Journal of Business Research, 68(1), 74-80. https://doi.org/10.1016/j.jbusres.2014.05.005

Marie Therese S. Sario. (2018). A Spatial Econometric Model for Houshold Electricity Consumption in the Philippines. Sereal Untuk, 51(1), 51.

Mustaqim, Setiawan, Suhartono, \& Ulama, B. S. S. (2019). Labor absorption and the growth of agricultural output: A simultaneous spatial durbin panel data model perspective of fiscal decentralization's impact in Indonesia. Journal of Advanced Research in Law and Economics, 10(4), 1182-1194. https://doi.org/10.14505/jarle.v10.4(42).18

Saeed, T. U., Nateghi, R., Hall, T., \& Waldorf, B. S. (2020). Statistical Analysis of Area-wide Alcohol-related Driving Crashes: A Spatial Econometric Approach. Geographical Analysis, 52(3), 394-417. https://doi.org/10.1111/gean.12216

Sainsbury, D. (2020). Toward a dynamic capability theory of economic growth. Industrial and Corporate Change, 29(4), 1047-1065. https://doi.org/10.1093/icc/dtz054

Seya, H., Tsutsumi, M., \& Yamagata, Y. (2012). Income convergence in Japan: A Bayesian spatial Durbin model approach. Economic Modelling, 29(1), 60-71. https://doi.org/10.1016/j.econmod.2010.10.022

Surya, B., Menne, F., Sabhan, H., Suriani, S., Abubakar, H., \& Idris, M. (2021). Economic Growth, Increasing Productivity of SMEs, and Open Innovation. Journal of Open Innovation: Technology, Market, and Complexity, 7(1), 1-37. https://doi.org/10.3390/joitmc7010020

Syam, R., Sukarna, \& Nurmah. (2020). Analisis Tingkat Kesejahteraan Masyarakat di Provinsi Nusa Tenggara Barat Menggunakan Model Regresi Multivariat. Journal of Mathematics, $\begin{array}{lll}\text { Computations, and } \quad \text { Statistics, } & \text { 97-108. }\end{array}$ https://doi.org/https://doi.org/10.35580/jmathcos.v3i2.19189

$\mathrm{Xu}$, A., Zhang, C. H., \& Ruther, M. (2020). Spatial dependence and spatial heterogeneity in the 
87 | JTAM (Jurnal Teori dan Aplikasi Matematika) | Vol. 5, No. 1, April 2021, pp. 80-87

effects of immigration on home values and native flight in Louisville, Kentucky. Journal of Urban Affairs, 00(00), 1-23. https://doi.org/10.1080/07352166.2020.1761257

Yolanda, A. M., Yunitaningtyas, K., \& Indahwati. (2019). Spatial Data Panel Analysis for Poverty in East Java Province 2012-2017. Journal of Physics: Conference Series, 1265(1). https://doi.org/10.1088/1742-6596/1265/1/012027 